\title{
Identifying Critical Junctures in Macroeconomic Policy - The Cases of Mexico and Sweden in the Early 1980s
}

\author{
Ana Ligia Haro Maza and John Hogan*
}

Dublin Institute of Technology, Aungier Street, Dublin 2, Ireland

\begin{abstract}
This paper utilizes a new critical junctures framework to help understand the nature of the changes in macroeconomic policy. The framework consists of three elements which must be identified in sequence to be able to declare, with some certainty, if an event was a critical juncture. These are crisis, ideational change, and radical policy change. Utilizing the critical juncture framework, we will determine whether changes to Mexican and Swedish macroeconomic policy in the early 1980 s constituted clean breaks with the past, or were continuations of previously established policy pathways, and why that was.
\end{abstract}

Keywords: Critical junctures, macroeconomic crisis, ideational change, policy change privatization policy.

\section{INTRODUCTION}

We employ the critical juncture framework developed by Hogan and Doyle [1]. According to this, a critical juncture consists of crisis, ideational change, and radical policy change (see Fig. 1). The framework rests upon the hypothesis that a crisis induced consolidation of a new idea - replacing an extant idea - can lead to significant policy change. The framework can explain why certain crises lead to critical junctures in policies whereas others do not, as the differentiating factor between them was ideational change. The framework contests that in the absence of ideational change the level of policy change, in response to a crisis, can be of the first or second order, but not the third. ${ }^{1}$ Policy instrument settings, and the instruments themselves, may change, but without ideational change the hierarchy of goals underpinning a policy will remain unaltered. Ideational change is the intermediating variable between a crisis and the subsequent nature of policy change in response to that crisis.

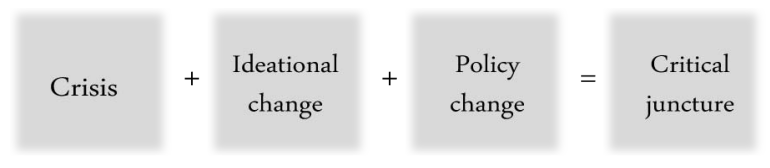

Fig. (1). Critical juncture approach.

This framework has been used to examine changes in macroeconomic policy in America, Britain, and Ireland, and privatisation policy in Brazil and Argentina. In this case, the macroeconomic difficulties affecting both Mexico and Sweden at the start of the 1980s will be examined to see if they

*Address correspondence to this author at the Dublin Institute of Technology, Aungier Street, Dublin 2, Ireland; E-mail: john.hogan@dit.ie

${ }^{1}$ Here the model borrows from Hall's (1993) concept of first, second and third order change. constituted crises, and, if so, did these crises lead to changes in the ideas underpinning macroeconomic policy, and the subsequent nature of the change in Mexican and Swedish macroeconomic policy. Were the macroeconomic policies in Mexico and Sweden in the early 1980s a continuation of, or break with, the past?

\section{THE CHARACTERISTICS AND USES OF THE CRITICAL JUNCTURES APPROACH}

Critical junctures are seen as branching point that set processes of institutional, or policy change, in motion. A critical juncture occurs when a new institution/policy is created, or when an extant institution/policy changes completely. The literature sees critical junctures resulting in the adoption of an institutional arrangement from among alternatives [2]. Thereafter, the pathway established funnels units in a particular direction $[3,4]$.

For some, a critical juncture constitutes a brief period in which one direction or another is taken, while for others, it is an extended period of reorientation [5]. The concept has been employed in comparative politics. Critical juncture frameworks have been used in the analyses of Latin America $[5,6]$. For them critical junctures took decades to occur. In relation to short term change, Garrett and Lange [7: p. 628] showed that electoral landslides created critical junctures by producing mandates for policy change. Casper and Taylor [8] employed the concept in analysing liberalisation of authoritarian regimes, while Hogan's [9, 10] remoulded framework was used to examine change in trade union influence over public policy. Karl [11] employed the concept in analyzing how "petro-states" became locked into problematic development pathways, while Flockhart [12] used critical junctures to explain the gap between the Danish population and their political elites' attitudes towards the European Union.

Critical junctures highlight the importance of the past in explaining the present. 


\section{THE COUNTRIES SELECTED FOR EXAMINATION}

Mexico and Sweden were selected for examination based upon most similar and most different criteria. For most similar we chose the criteria of having long-standing democracies and advanced capitalist states. They are most different according to Lijphart's [13] categories of majoritarian and consensual democracies, allowing us to control for varying institutional arrangements. Both countries' economies were very different, while their performances, and the policies governing them, have varied dramatically. Their geographic locations also provide for a global encompassing contrast. Thus, their similarities ensure "the contexts of analysis are analytically equivalent to a significant degree," while their differences place "parallel processes of change in sharp relief" [14: p. 2].

\section{POLICY CHANGE AND ITS IDENTIFICATION}

Policy change is complex, and must be seen in the context of societal and political change [15]. Utilizing Hogan and Doyle's [1] framework, we examine change in Mexican and Swedish macroeconomic policy in the early 1980s in discrete stages. The first stage examines the economy to see if it was in crisis. A crisis implies that prevailing policy cannot be sustained without deterioration [16]. An economic crisis, therefore, can influence policy preferences [17]. To test for an economic crisis we develop observable implications.

The framework's second stage tests for ideational change. New ideas can change the policy environment [18]. But, how ideas influence policy is something theorists have long grappled with [19]. This gives rise to questions: where do ideas come from? How do they relate to failing policies? And, why do the ideas underlying a failing policy sometimes change, resulting in policy change, whereas at other times they remains unaltered, resulting in policy continuation? To answer this, a second set of observables, based on Legro [20], are set out.

The framework's third stage tests for policy change. Here our observables are based upon the work of Hall [21], tying together the concepts of policy change, societal learning, and the state. Thus, each stage employs observable implications incorporating aspects of societal and political change.

\section{Testing for a Macroeconomic Crisis}

Scholars regularly 'agree that severe recessions make significant structural changes possible as they render politics highly fluid' [22: p. 522]. However, economic crises are rare, rendering definition and identification difficult [23: p. 439]. How do we identify a crisis? Stone [24: p. 299] argues that a situation does not become a problem until it is controllable. But, if something is controllable it must be measurable, otherwise how would we know if we are controlling it? Thus, even economic crises must be quantifiable.

Kaminsky, et al., [25] and Berg and Pattillo [26] advocated examining individual variables when quantifying currency crises. Pei and Adesnik [27: pp. 138-139] developed a broader range of criteria for identifying macroeconomic crises: annual inflation greater than 15 percent, stagnant annual gross domestic product (GDP), and historians and other analysts' descriptions of significant deterioration in economic circumstances. Frankle and Rose [28: p. 351] define a "macroeconomic crisis" as a stagnant economy, where investment is in decline, inflation, interest rates, and unemployment are above 15 percent, and various actors perceive the economy to be in crisis. For Garuba [29: p. 21], Kwon [30: p. 105], and Solimano [31: p. 76] a macroeconomic crisis can be identified through general indicators and perceptions of growth, inflation, employment creation, and poverty.

We seek to identify macroeconomic crises through quantitative and qualitative measures. Defining anything as a crisis, including a macroeconomic downturn, requires subjective and objective deliberations [27: p. 39]. Consequently, González [32: p. 93] suggests adopting a multifaceted approach. Agents must diagnose, and impose on others, their notion of a crisis before collective action to resolve uncertainty can take meaningful form [33: p. 9]. This fits with Hay's [34: p. 321] perception of a crisis as the triumph of a simplifying ideology.

Thus, we develop a range of observable implications, which build upon previous studies [1]. They seek to identify change in nominal economic performance as well as in perceptions of economic health.

01. If GDP growth was stagnant/negative, the economy may have been in crisis.

02. If total debt as a percentage of GNI was above 100 percent, the economy may have been in crisis.

03. If inflation was above 15 percent [27], the economy may have been in crisis.

04. If the interest rate was above 15 percent, the economy may have been in crisis.

05. If the unemployment rate was above 15 percent, the economy may have been in crisis.

O6. If opinion polls find the public regarded the economic in crisis, then the economy may have been in crisis.

07. If the national media regarded the economy in crisis, then the economy may have been in crisis.

O8. If economic and political commentators regarded the economy in crisis, then the economy may have been in crisis.

09. If the central bank regarded the economy in crisis, then the economy may have been in crisis.

010. If both domestic and international organisations monitoring economic performance regarded the economy in crisis, then the economy may have been in crisis.

011. If elected representatives regarded the economy in crisis, then the economy may have been in crisis.

012. If government pronouncements on the economy were consistent with a crisis management approach, then the economy may have been in crisis.

\section{Mexico - Potential Crisis 1981-1983}

After the Second World War Mexico sought growth through import substitution [35]. Domestic industries were developed behind import quotas [36, 37]. This increased the country's international trade, while decreasing its foreign 
dependence. However, Hernandez [38] pointed out competitiveness was not crucial for Mexican businesses, as the internal market was closed to foreign competition. Nevertheless, the model succeeded as there was a strong demand for Mexican raw materials. Hernandez [38] argued that Mexico's policies created a private sector with a mercantile mentality, that came to depend upon state protection.

Under President Echeverria's (1970-1976) poor decisions drove the economy into recession [35]. Serra-Puche [39] remarked that the Echeverria administration permitted fiscal and monetary discipline to collapse. This marked the exhaustion of the policy know as "stabilising development". Mexico's import substitution could not compete with global manufacturers such as Japan. Rubio [40] put the failures of stabilising development down to falling agricultural exports, rapid population growth, and a middle class disillusioned with its inability to express itself in a one party (Institutional Revolutionary Party (PRI)) dominated culture.

President Portillo (1976-1982) inherited a troubled economy [41]. However, huge oil reserves were discovered by Petróleos Mexicanos (PEMEX), the state oil company, in the late 1970s [42]. The hope was that oil revenues would stabilise the economy. Interviewees pointed out that this discovery permitted extant policies to soldier on. However, the oil boom only circumvented the dangers of immediate crisis, without resolving the structural problems in the economy [43]. Tournaud [44] argued this was evidence of the temporary solutions often sought by the Mexican political elite. Tournaud [44] blamed this short-termism on the institutional structure that permitted presidents only one term of office.

Once the country had become a net petroleum exporter pressure grew to expand public spending. Mexico's development strategy came to depend upon oil revenues. The number of state owned enterprises quadrupled to 1,200 [42, 45]. Expenditure came to outstrip revenues derived from petroleum and an anaemic taxation system [46]. To finance these projects Mexico had borrowed \$78bn. by 1981 [41].

This expenditure began to overheat the economy by the late 1970s (Appendix A). By this time the state's share of fixed capital formation had increased to 50 percent [47: $p$. 277]. As inflation rose above 25 percent the peso became overvalued, and the competiveness of exports, apart from oil, diminished [48]. 'The merchandise trade balance deteriorated' as 'imports rose while nonoil exports earning stagnated' [49: p. 494].

Mexico was poorly positioned to resist the financial challenges of the early 1980s as oil prices fell in response to a weakening world economy and a supply glut [50]. To compound matters, PEMEX and the Secretaría de Programación y Presupuesto (SPP), published a report clarifying that oil production would not be sufficient to reactivate the economy [51]. Problems in the US meant that as interest rate increased there, the money supply diminished. As Starr [52: p. 53] puts it 'collapsing oil prices and rising international interest rates erased Mexico's economic prosperity'. The result was that foreign borrowing became a requirement to sustain expansion.

Higher US unemployment lowered demand for Mexican goods. The sharp increase in US interest rates placed increas- ing pressure on Mexico's debt servicing, as US banks had lent the country some $\$ 25$ billion. Servicing Mexico's total debt reached $\$ 16$ billion, more than the country's revenues from oil [53: p. 89].

By 1982, as confidence in the economy waned, Mexicans began converting pesos into dollars at up to 25 billion pesos a day [54]. To reduce the flow of capital out of the economy Banco de Mexico permitted the dollar price of the peso to double. However, the gravity of the situation came to international attention on August 13, 1982, when:

The government fired the shot heard around the world, announcing that it could not meet interest payments coming due within the next few days and initiating negotiations for bridge loans and rescheduling agreements with the US Treasury, the IMF, and the private commercial banks [43: p. 97].

Mexico's main economic indicators pointed towards a crisis (Appendix A) [55]. GDP contracted by 0.6 percent in 1982 and a staggering 4.2 percent in 1983 , while the rate of inflation reached 58.92 percent in 1982 [56]. Unemployment jumped towards 15 percent [57], while more than 20 million people, more than half the workforce, were underemployed [53: p. 92]. Output fell in all industries, mineral production declined by 10 percent, auto production 20 percent, and agriculture 20 percent [57]. To compound matters US banks stopped lending to Mexican companies as they already owed over US $\$ 600$ million in interest [58]. The budget deficit stood at a staggering 16.5 percent of GDP [57].

In 1983 inflation reached triple digits, the national debt and unemployment continued to rise, and the level of capital formation slackened (Appendix A). Time Magazine pointed to the dramatic devaluation of the peso against the dollar [59]. According to Edwards [60: p. 17] this was the worst crisis to hit Mexico since the Great Depression. The Third World Magazine [61], Gestión y Estrategia [62], and Time Magazine [63] referred to Mexico's economic difficulties as a crisis. The Economist regarded Mexico as the country most affected by the crises of the 1980s [64]. Spanish newspaper El País, stressed that Mexico's crisis was partly due to the policies of President Portillo [65]. Mexican economic magazine Proceso regarded the 1982 crisis as Mexico's worst recession [66].

Confidence in Mexico's economy, and politicians, evaporated. Hernandez [38] stated that the situation left the country without financial security. The Third World Magazine argued the country was effectively bankrupt [67]. William Perry of Georgetown University observed that the crisis was a sign that Mexico's traditional political system was decaying [57]. Minimum wages were insufficient to meet the basic needs of most Mexican families. Prices for staples increased at least 400 percent at the beginnings of 1982, while wages increased by just 300 percent [68]. Opinion polls found great scepticism concerning the economy [69]. The decision to nationalise the banks, to decrease foreign investors' panic, and the continued speculation against the peso, was a last desperate measure by President Portillo [70].

During 1982 the peso was devaluated twice [71]. The hope was that devaluation might increase exports, but the economy could not hold onto a sufficient amount of dollars [72]. New short term loans were taken in an effort to coun- 
teract the capital flight, but, together with the peso's devaluation, this did nothing [73]. Banco de Mexico's reserves dried up in a matter of weeks [74]. In his Sixth Annual Presidential Report, Portillo stated that the economy was going through the worst crisis in its history [75].

Sandersen [76] points to three issues that exacerbated Mexico's problems: (i) economic policy was directed by a coalition of political leaders; (ii) stability of the PRI was threatened by opposition parties; (iii) economic demands of oil-rich Mexico could no longer be sustained by the policy framework. Furthermore, Bailey [77: p. 54] identified four trends that produced the economic panic: oil price fall/excessive government outlays; $\$ 15.3$ billion in shortterm loans which funded capital flight; overvalued peso; and high dollarization.

Under Portillo GDP grew at 8 percent annually from 1978 to 1981 , one of the highest levels in the world. However, by the beginning of 1982, Mexico had run up a huge national debt, and drastically devalued its currency. By the end of 1982, Mexico faced one of the severest macroeconomic crises in its history [78, 79].

\section{Sweden - Potential Crisis 1981-1983}

The recession that began in the mid-1970s, as a result of the first oil shock, proved persistent. Central government's expenditures grew at a faster pace by the end of the 1970s than they had at the beginning of that decade, while revenues stagnated due to slow economic growth. The consequential budget deficits were largely financed through borrowing from abroad. However, there was no political mandate for either radical budget cuts or revenue enhancements. The non-socialists parties in government (Centre, Liberals and Moderates) wanted neither to raise the level of taxes nor be accused of trying to dismantle the social welfare state they had only recently taken power over, after decades out in the cold [80].

By 1982 the Swedish economy was in difficulty, with the media, national commentators, domestic and international organisations, and the central bank, all pointing this out. With a sluggish national economy, stagnant revenues, and rapidly rising expenditure, the government's budget deficits accelerated during the late 1970 s, so that by 1982 they had reached a very worrying 13 percent of GNP [81: p. 17]. The Riksbank predicted that 'the deficit on the national budget, which the non-Socialist Government had struggled to contain over the pervious two years, would grow from around SKr78 billion under the 1982-83 budget to some SKr90 billion in 1983-1984' [82: p. 32]. 'In an international context, both the level of the budget deficit, and the swing in the budget balance since the mid-1970s has been more pronounced than in most other OECD countries' [83: p. 16]. By 1982 Sweden's ratio of debt of GNP stood at 59.3 percent. An indication of just how substantial the budget deficits were can be ascertained from the fact that the debt to GNP ratio had stood at 50.8 percent just 12 months before. In all, the Swedish debt to GNP ratio had grown by over 250 percent in the space of just six years! The Economist [84: p. 41] observed that inflation was running at 8.6 percent in 1982, although significantly down on 1981's rate of 12.1 percent, this figure was still very high for Sweden. Unemployment, having hovered at between 1.5 and 2 percent throughout the 1970s, had reach 3.1 percent in 1982, its highest level since 1945. Although this would have been a miniscule figure anywhere else, it was a political scandal in a country accustomed to full employment [85: p. 3]. For Swedes this was an unprecedented situation.

However, some economists believed that the [unemployment] figure would have been closer to 16 percent if it included the jobless who are in training programmes and public work projects, workers who have been forced into early retirement, and Swedes who have given up looking for work [80: p. 32].

Yet, apart from unemployment, and the debt to GNP ratio, none of the other indicators set out in Appendix B were at decade-long lows. Economic growth, which had averaged 2.5 percent throughout the fluctuation economic conditions of the 1970s, stood at a mere 1 percent in 1982, after in fact contracting the previous year. Although only 2,000 days were lost to industrial disputes in 1982, 209,000 had been lost in 1981, while 4,478,000 days were lost in 1980 [86]. Nevertheless, in the context of the international recession of the early 1980s, the large budget deficit prevented the government from pursuing a counter-cyclical fiscal policy. Consequently, Sweden had to accept the impact of recession from abroad.

The Washington Post pointed out that at this time the Swedish economy faced serious economic challenges [87: $\mathrm{p}$. A15]. 'The country, like most in Europe, now suffers from low growth, falling industrial output and an unfavourable trade balance' observed the New York Times [88: p. 17]. The paper went on to argue that the Swedish economy, once the envy of Europe, had been hobbled by its foreign debt, a low rate of investment, an adverse balance of payments, and its level of unemployment [85: p. 3]. The Financial Times pointed out that Swedes were nervous about the future, and reluctant to see their welfare state cut back and to accept the tough remedies proposed to deal with their growing economic problems [89: p. 15]. "The welfare state is in a major crisis of legitimacy,' observed Hans Vetterberg, Sweden's leading pollster and public opinion analyst. 'We can no longer afford to keep expanding it the way we were" [87: p. A15].

The OECD [83: p. 49] described the situation in the Swedish economy in the spring of 1982 as difficult. Economic performance in the two years to mid-1982 had been poor, this partly influenced by the weak international environment. Furthermore, in spite of the adjustment policies pursued by the authorities, correction of the large imbalances that had built up since the early 1970s was slow, and the economy remained in a situation of marked disequilibrium [90: p. 7]. Apart from maintaining a relatively good level of employment the government's economic policies were not successful. The government's budgetary position weakened sharply, with the growth in public expenditures greatly outstripping that of the overall economy [90: p. 9]. The OECD [90: p. 12] further pointed out that foreign competition had made substantial inroads on the Swedish domestic market, as suggested by the steady rise in the imported share of manufactured goods used domestically.

Ironically, the public sector's share of GNP had risen rapidly under the non-socialists, so that by 1982 public sec- 
tor expenditure constituted some 67 percent of GNP [91: p. 59]. That level of spending explained in part how the number of jobs in the public sector could rise by 43 percent between 1972 and 1982, coming to outnumber jobs in private industry after 1978 [92: p. 123]. Worryingly, Peterson [93: p. 33] points out that Sweden's share of the world economy dropped by some 40 percent during the same ten-year period. Labours' productivity growth from about 1970 onwards was markedly less impressive than prior to then. The sluggish aggregate productivity growth in Sweden after 1970 was to some extent the result of the large size of the public sector, and labours' slow productivity growth [94: p. 1312]. Thus, by the 1980s, the Swedish economy, once the envy of Europe, had been hobbled by crisis [85].

From Table $\mathbf{1}$ it is clear that the Mexican economy was in crisis during the early 1980s, with all observable implications satisfied by our findings. It is also clear from Table $\mathbf{1}$ that Sweden, although it did not satisfy all observable implications, satisfied most - three-quarters. This information, combined with the fact that the economic conditions existing in Sweden at this time were totally out of context for that society, and that there was much hidden unemployment, leads us to declare that it too was in economic crisis in 1982. The next section examines both countries for changes in the ideas underlying macroeconomic policy at this time.

Table 1. The Identification of Macroeconomic Crisis

\begin{tabular}{|l|l|l|}
\hline The Observable Implications & Mex & Sw \\
\hline \hline O1. Was GDP growth stagnant. & $\mathrm{X}$ & $\mathrm{X}$ \\
\hline O2. Was total debt above 100\% of GNI? & $\mathrm{X}$ & \\
\hline O3. Was inflation above 15\%? & $\mathrm{X}$ & \\
\hline O4. Was interest rate above 15\%? & $\mathrm{X}$ & $\mathrm{X}$ \\
\hline O5. Was unemployment above 15\%? & $\mathrm{X}$ & \\
\hline O6. Opinion polls- economy in crisis? & $\mathrm{X}$ & $\mathrm{X}$ \\
\hline O7. Media - economy in crisis? & $\mathrm{X}$ & $\mathrm{X}$ \\
\hline O8. Econ/pol commentators - economy in crisis? & $\mathrm{X}$ & $\mathrm{X}$ \\
\hline O9. Central bank - economy in crisis? & $\mathrm{X}$ & $\mathrm{X}$ \\
\hline O10. Dom/ int orgs - economy in crisis? & $\mathrm{X}$ & $\mathrm{X}$ \\
\hline O11. Reps - economy in crisis? & $\mathrm{X}$ & $\mathrm{X}$ \\
\hline O12. Gov - crisis management approach? & $\mathrm{X}$ & $\mathrm{X}$ \\
\hline Economic Crisis & $\mathrm{Y}$ & $\mathrm{Y}$ \\
\hline
\end{tabular}

\section{Testing for Ideational Change}

Previous policies can be discredited due to their implication in, or inability to right, a crisis [95]. Although economic crises can have great impact they will not determine policy, whose formulation is 'centred in domestic political and ideational processes' [96: p. 375]. Hogan and Doyle's [1] framework contends that significant policy change depends upon actors reaching consensus upon, and subsequently consolidating around, a particular set of new ideas. This corresponds to McNamara's [96: pp. 4-5] argument that actors utilize new ideas to chart policy strategy. 'Ideas facilitate the reduction of ... barriers by acting as coalition-building resources among agents who attempt to resolve the crisis' [33: p. 37]. Ideas are the casual mechanisms of change in any critical juncture [97]. Thus, ideational change stands between a crisis and policy change, determining if a crisis will result in policy change.

Hogan and Doyle's [1] framework contents that new ideas are introduced by three groups of change agents. Combinations of these agents constitute a policy network [21]. The most important are what Dahl [98] termed 'political entrepreneurs'. Political entrepreneurs 'exploit moments of instability' and 'invest resources in the creation of a new policy, a new agency, or new forms of collective action' [99: pp. 188-190]. In a crisis, a political leader, usually an opposition leader, will seek out new ideas to rectify the ills of the existing policy paradigm. The second group are Kingdon's [100: pp. 179-183] 'policy entrepreneurs'. These are agents who spread ideas to replace the current paradigm. They may be civil servants, technocrats, academics, economists and interest groups. The final group of change agents consists of outside influences: the media, the Organisation for Economic Co-operation and Development (OECD), the International Monetary Fund (IMF) and the World Bank. They critique an existing economic paradigm, advocating a new one. Both policy entrepreneurs and outside influences are responsible for producing ideas, but, political entrepreneurs introduce ideas into the policy process.

According to Legro's [20: p. 419] two-stage model of ideational change, if agents agree the existing ideational paradigm is deficient and should be replaced, the first stage ideational collapse - has occurred. These are the observables for ideational collapse:

\section{Ideational Collapse}

01. The media questions the efficacy of the current model/specific policy areas.

O2. Opposition political parties critique the current model and propose alternative ideas - at election time their platform will be built around these alternatives.

03. Civil society organizations, e.g. labour unions, employer organizations, consumer groups etc. critique the current model, reflecting Hall's [21: p. 12] coalition-centred approach.

04. Widespread public dissatisfaction with the current paradigm, observable through opinion polls, protests etc.

O5. External/international organizations critique the current model and/or actively disseminate alternative ideas.

Agents will then propose a range of solutions, with one main challenger to the dominant creed. However, 'even when ideational collapse occurs, failure to reach consensus on a replacement could still produce continuity, as society reflexively re-embraces the old orthodoxy' [20: p. 424]. The crucial issue is reaching consensus on a new set of ideas. If consensus is achieved it marks the second stage of Legro's model - consolidation - agents coordinating a replacement set of ideas. This can be seen in political entrepreneurs con- 
solidating innovations by combining a mixture of interests to produce a winning coalition [99: pp. 192-193]. Oliver and Pemberton [101] identified this process as policy learning. Below are the observables for new ideational consolidation.

\section{New Ideational Consolidation}

O6. A clear set of alternative ideas, developed by policy entrepreneurs, are evident.

07. A clear change agent (political entrepreneur) injecting new ideas into the policy arena is evident.

08. The political entrepreneur combines a mixture of interests to produce consensus around a replacement paradigm.

Policies are protected by underlying ideas [102]. The greater the consensus encompassing an idea the more protected the policies derived from it. Protected policies represent continuity, whereby once a policy has become institutionally embedded, 'policy-making becomes possible only in terms of these ideas' [103: p. 4]. Referring to policies as protected is similar to Golob's notion of 'policy frontiers' [97: 363].

\section{The Ideas Underlying Mexican Macroeconomic Policy}

Populist-redistributive models were implemented by PRI presidents between 1934 and 1976 [76: p. 319]. When Portillo came to office he was forced to contemplate reduced expenditure due to the economic downturn in the wake of the oil crisis [103]. However, the discovery of vast oil reserves changed everything, with Portillo adopting a patronage model. This embraced trade expansion and liberalisation, rapid industrialisation and expansive state expenditure [77]. Portillo's continuation of the populist approach produced high growth, however, the economy remained vulnerable.

Rather than pay the political price that sweeping redistributive policies-especially tax reform-would have entailed, both the Echeverria administration (1970-1976) and the Portillo administration (1976-1982) sought to expand the entire economic pie and increase the role of the state in the economy, as banker, entrepreneur, and employer [53: p. 88].

Despite oil revenues, the economy became fuelled on foreign borrowing and declining real wages [104]. However, once oil prices fell, and interest rates spiked, Mexico faced the prospect of debt default. The ideas underlying extant economic policy underwent a rethink. By mid March 1982, President Portillo's administration introduced a 12 point plan to stabilise the economy [105].

During the 1982 presidential election all contenders focused on the crisis. Miguel De La Madrid, a fiscal conservative, was selected as PRI presidential candidate in September 1981 [106]. He was 'among the leaders of the conservative faction based in the treasury' [43: p. 98]. The mechanics of this selection process were hidden [76: p. 320], but it appears that shifts in a more conservative direction within inner circles of the PRI led to the choice of De La Madrid [107]. Mexican society was in turmoil, and free market supporters wanted a president who would support the rights of private property [108]. In an interview Cárdenas [109] remarked that the choice of De La Madrid marked a rupture within the PRI from its revolutionary ideology. There was a feeling that the
PRI, and traditional politics, was failing to meet the challenges confronting Mexican society.

During his campaign, De La Madrid stressed the differences between his proposed government and that of Portillo. "Crises come about because the government tries to consolidate all interests at the same time..." declared De La Madrid [110: pp. 1-2]. His proposed government would mobilise resources to change the direction of the economy [110]. 'In the post-1982 environment, policy options and instruments appeared limited [for Mexico], which as a debtor was subject to the conditionality imposed by the International Monetary Fund (IMF)' [97: p. 375].

In his inauguration address De La Madrid declared opposition to populism and institutional corruption [53: p. 93]. He stated that a new moral, political and economic approach was needed [111]. Locked into a harsh IMF bailout, negotiated by the outgoing administration [112], De La Madrid presented a detailed programme for policy change [113].

In his new approach to managing the economy, De La Madrid, acting as a political entrepreneur, kept Silva-Herzog in the treasury, and Miguel Mancera Aguayo in the Central Bank [57], while selecting 11 new ministers from the conservative wing of the PRI [43: p. 95]. His aim was to take policy to the right. In this regard, his cabinet broadly supported his measures to stabile and open the economy [114, 115: p. 28]. In Mexico access to the president was the only means of influencing policy; thus policy entrepreneurs cultivated teams of loyal followers within various bureaucracies [97: p. 383].

The De La Madrid administration had a limited range of policy options. As Hernandez [38] stated, sources of external finance dried up in the aftermath of the crisis, while oil revenues remained stagnant. Even when oil prices rose, the Mexican oil industry did not have the capacity take advantage of this. Macroeconomic stabilisation became the priority [116: p. 421]. These decisions were applied across all government policies [53: p. 107]. To maintain economic, political, and social order, a break with the past was required. The De La Madrid administration gave priority to greater integration into the world economy by attracting foreign direct investment (FDI); and focusing on high tech industries.

\section{The Ideas Underlying Swedish Macroeconomic Policy}

In the spring of 1981 the non-socialist coalitions government and the opposition Social Democrats Socialdemokratiska Arbetarepartiet (SAP) reached agreement on ways of reducing marginal taxation. However, this agreement led to a dispute within the coalition that saw the Moderates resign from the government. Prime Minister Thorbjorn Fälldin formed a new minority Government of the two middle parties (Centre and Liberal), his third Cabinet in five years. Both of these parties had suffered losses in the general election of 1979, and between them held a total of only 102 of the 350 seats in the Riksdag [117]. This minority government hoped that its active program to combat Sweden's economic problems would generate respect for non-socialist policies. However, declining popularity figures plagued the new administration [84]. A mounting central government budget deficit, a negative balance of payments, and rising unemployment figures showed that the economic crisis was a reality [86: p. 7]. Swollen social welfare expenditures only 
added to the crisis. The welfare state was becoming dysfunctional for capital [118: p. 81). In the autumn of 1981 Sweden carried out a 10 percent devaluation of the krona, and in the spring of 1982 the non-socialist government introduced a far-reaching austerity program. However, the opposition Social Democrats gained ground while the two governing parties noted the steady erosion of their popularity in the opinion polls [119: pp. 129-130].

The 1982 election was deemed crucial as it would determine whether public support had shifted, as in Norway and Denmark, away from the Social Democrats. The election campaign was dominated by talk of economic crisis - a $\$ 10$ billion debt to foreign banks, inflation, declining exports, and increasing unemployment [87]. During the campaign the Social Democrats under Olof Plame attacked the viability of another non-socialist government, and their economic policies. The party presented a program on how Sweden could save and work its way out of crisis. Ultimately, the election, and the debates surrounding it, failed to generate either a coherent set of alternative economic ideas to replace the existing ones, or a significant agent of change. The nonsocialist parties failed to create a coalition of interests around ideas alternative to those of the welfare state. Nearly all economic ideas presented were variations on existing themes. Despite the dominant orthodoxy's failure society reflexively re-embraced it as there was no political entrepreneur championing any viable alternatives developed by policy entrepreneurs. The ideas underpinning the policies of the welfare state endured. The SAP won the election, not on the back of a new economic paradigm that could cure the country's woes, but, on a series of proposals to correct existing economic arrangements.

Table 2. The Identification of Ideational Change

\begin{tabular}{|l|l|l|}
\hline The Observable Implications & Mex & Sw \\
\hline \hline Ideational Collapse & & \\
\hline O1. Media questioning efficacy of current model & $\mathrm{X}$ & $\mathrm{X}$ \\
\hline O2. Opposition parties critique current model. & $\mathrm{X}$ & \\
\hline $\begin{array}{l}\text { O3. Civil society organisations critique the current } \\
\text { model }\end{array}$ & $\mathrm{X}$ & \\
\hline $\begin{array}{l}\text { O4. Widespread public dissatisfaction with current } \\
\text { paradigm }\end{array}$ & $\mathrm{X}$ & $\mathrm{X}$ \\
\hline O5. Ext/int organisations critique current model & $\mathrm{X}$ & $\mathrm{X}$ \\
\hline & $\mathrm{Y}$ & $\mathrm{Y}$ \\
\hline New Ideational Consolidation & $\mathrm{X}$ & \\
\hline O6. A clear set of alternative ideas are evident & $\mathrm{X}$ & \\
\hline O7. A clear change agent & $\mathrm{X}$ & \\
\hline $\begin{array}{l}\text { O8. Political entrepreneur combines interests to pro- } \\
\text { duce consensus }\end{array}$ & $\mathrm{Y}$ & $\mathrm{N}$ \\
\hline Adoption of New Idea & \\
\hline
\end{tabular}

From Table 2 it is clear In the case of Mexico ideational change followed macroeconomic crisis. The ideas underpinning macroeconomic policy, focused on import substitution industrialisation, collapsed. Vast expenditure, based upon the belief that oil revenues could support rapid industrialisation, led the country to the brink of bankruptcy. De La Madrid, acting as a political entrepreneur, implemented a new set of ideas on how to manage the economy. These involved moving the economy away from import substitution, towards a more open approach to international trade.

At this time Sweden was also experiencing unfulfilled economic expectations, and change agents there were dissatisfied with the prevailing economic paradigm. This constituted extant ideational collapse. However, unlike in Mexico, although extant ideas on how to manage the economy had collapsed, in the wake of the economic crisis, change agents in Sweden failed to consolidate around a replacement economic orthodoxy. One of the reasons for this failure was that no political entrepreneur came forward to champion an alternative set of ideas to those underlying social democracy. The result was that a new set of ideas on how to manage the Swedish economy did not emerge in 1982.

\section{Identification of Policy Change}

McNamara [97] argues that new ideas change the wider policy environment. The level of policy change depends upon the preceding variables, but is also central to determining if there has been a critical juncture. We hypothesise that once there is political entrepreneur led consolidation around a new set of ideas policy change should follow. We argue that ideational change constitutes the "differentiating factor" between crises that result in radical policy change, and those that do not. Therefore, we must discover if radical changes in economic policy follow ideational change. The observable implications used here are based upon Hall's [21] concepts of first, second, and third order policy change. Hall [21: p. 291] argued that exogenous shocks, and policy failures, discredit the old paradigm, leading a re-examination of the belief systems through which that policy was created - a paradigmatic change. He describes rare, but radical, and overarching changes in policy as third order changes. The observables set out below enable us identify, and differentiate, the normal and fundamental shifts in macroeconomic policy. They also incorporate the idea of swift and enduring change [9].

01. If economic policy instrument settings changed (swiftly and for longer than one government's term of office) there may have been a radical change in government economic policy.

02. If the instruments of economic policy changed (swiftly and for longer than one government's term of office) there may have been a radical change in government economic policy.

O3. If the hierarchy of goals behind economic policy changed (swiftly and for longer than one government's term of office) then there may have been a radical change in government economic policy.

\section{Change in Mexican Macroeconomic Policy}

The first policy response to the crisis came from the Portillo administration. It sought to ensure that financial policy would keep domestic interest rates competitive [120: p. $112]$, while incentives were created for exports. For decades 
free trade was 'the policy option that dare not speak its name' [78: p. 370].

In his inaugural address in December 1982 De La Madrid declared "we are in an emergency" [57]. He outlined a tenpoint austerity program - Programa Inmediato de Reordenacion Economica (Program of Immediate Economic Reorganization) [121: p. 29]. He adopted a crisis management approach, sending a draconian budget to Congress for a 50 percent reduction in the deficit [57]. The budgets of 19821984 represented a sustained attempt at austerity [53: p. $117]$.

De La Madrid pegged the peso at a more "realistic" exchange rate and introduced plans to restructure the federal bureaucracy. He set about implementing conventional monetary and fiscal austerity, more extensive trade liberalisation, and a less confrontational approach to the IMF [43: p. 63]. The IMF Managing Director, Jacques De Larosiere, and the Mexican finance minister, Silva-Herzog, negotiated an adjustment program to restore the economy. 'Acceptance of the IMF embrace is a major break-through' [122: p. 1720], as it permitted Mexico avoid the dangers of a debt moratorium [120: p. 121].

De La Madrid recognised that his administration could not rely on oil's exports [68]. Hernandez [38] argues that the solution to financing the country's development was sought through privatising public enterprises, of which 1,155 were sold off. De La Madrid sought to combine macroeconomic stabilisation and structural change, with a focus on export orientated manufacturing [53: p. 110]. This was part of the overall objective of integrating Mexico into the world economy. De La Madrid disbursed power to the states, to foster increased competitiveness within the country, and support private industry and investment [123].

The initial adjustment package sought to ameliorate the external debt through a reduction of government spending and a one-time devaluation of the peso. This enabled Mexico reach its IMF targets for reducing the public sector deficit and limiting new public sector external indebtedness. Unfortunately, the recessionary impact of this strategy was more severe than anticipated, and much of the task of economic adjustment was left to De La Madrid's successor [116: p. 421].

The ideas underlying state-led development, based on import substitution industrialisation collapsed. The government 'embraced an approach generally oriented toward liberalisation, privatisation and deregulation' [116: p. 421]. As an interviewee stated - the change from stabilising development to neo-liberalism was radical.

These policies were to have an impact upon Mexico's future economic, and social, development [53: p. 84]. Mexico's import substitution policies had been centred on encouraging the internal market, while the new approach focused on using international forces as promoters of liberalisation [124]. However, a major concern was Mexico's inability to compete in foreign markets, and its inadequate level of internal saving to finance growth [125]. De La Madrid's administration signalled its desire to attract new foreign investment by offering to relax restrictive FDI laws. In February, 1984, the government issued guidelines specifying new conditions under which officials could authorize majority foreign ownership of firms [53: p. 115]. Tournaud [44] stated that once this occurred Mexican businesses began forging relationships with foreign firms.

According to Middlebrook [124] the relationship between the private sector and the state transformed. The neoliberal reforms made the private sector a key player in reviving the economy. According to Hernandez [38] and Tournaud [44] this was the main difference between De La Madrid's administration and those of his predecessors. Business organisations became more actively engaged in public debates over economic policy. For decades the private sector had been kept at a distance by the PRI [97: p. 371].

De La Madrid's approach focused on development with a social objective, but based on economic reality [125]. According to Foucras [126] under De La Madrid all sections of society gained a voice. Cárdenas [109] argues that this would become an important factor in the movement of national liberalisation started in the early 1980s, and strongly embraced during De La Madrid's presidency. For Rubio [40] and Hernandez [38], political reform changed the country's social ideology.

Serra-Puche [39] and Cárdenas [109] argue that Mexican economic history can be divided into before, and after, 1982. Mexico started down a different path under De La Madrid (1982-1988). The crisis saw the development of a new set of policies. In the wake of crisis, and change in the ideas underlying economic policy, Mexico experienced a thirdorder macroeconomic policy change. The market replaced regulation, private ownership replaced public ownership, and competition replaced protection [127: p. 85; 116: p. 421]. According to Hernandez [38] and Foucras [126], there was a change in Mexico's economic model, which culminated in its accession to the North American Free Trade Agreement (NAFTA) in 1993.

\section{Change in Swedish Macroeconomic Policy}

The recession of the 1970s saw the Swedish budget deficits supporting the social welfare system deepen. By 1981 the non-socialist coalition government was only a minority administration in the Riksdag [117]. Not surprisingly, the Swedish Employers' Federation (SAF) was unhappy with the government over the state of the economy. However, the non-socialist government displayed great indecisiveness in relation to dealing with the economic malaise [80].

The only tangible result of the change of government in Sweden in 1982 was an altered approach to economic management, with only minor changes in extant economic policies. The new SAP government, admitting there were no ready solutions to the economy's problems [85], implemented a recovery programme - The Third Road. This approach argued that renewed growth required redistribution of income from labour to capital. It constituted a shift in SAP economic planning, behind which course lay the influence of its own research unit, as opposed to those of the unions. This marked an attempt to maintain a level of social democracy, which other countries were rolling back [128, p. 134]. The Third Road sought to devise a wide-ranging stabilisation programme that included demand management measures, as well as initiatives to promote structural change and ensure the fair distribution of the burden of adjustment [91: p. 21]. 
The SAP was also determined to pour funds into job creating industries, and even to increase taxes for that purpose [129]. The party planned to spend $\$ 100$ million, and hoped to attract an addition $\$ 350$ million in private investment, in order to create 30,000 new jobs [129]. The centrepiece of Finance Minister Feldt's strategy to boost corporate profits was devaluation of the krona. This measure was implemented, in conjunction with a price freeze and increases in sales and corporate taxes, in a sweeping "crisis plan" aimed at stimulating the economy and correcting the fundamental imbalances therein $[130,131]$. According to the OECD [91, p. 21] the objective was to achieve export-led, investment driven, recovery. The SAP had identified labour costs as the key to international competition. The country's largest peak trade union organization, the Landsorganisationen i Sverige (LO) accommodated devaluation by demanding average wage increases of only 2.5 percent in ensuing wage bargaining. However, the devaluation drew international opprobrium. "The danger of a chain reaction of beggar-thyneighbour policies with potentially disastrous consequences is now greater that at any time since World War II," said Emil Van Lennep, secretary general of the OECD [132: p. 3]. The devaluation and international economic recovery resulted in high earnings and excellent scope for export expansion [133: p. 333].

The government also restored welfare entitlements cut by the non-socialists [91: p. 23]. To maintain the welfare state by whatever means necessary the government gave priority to private sector growth, profits and market forces. It introduced a series of structural reforms that could be regarded as redefining the traditional priorities of the SAP. Under pressure for more individual freedom, and the internationalisation of the economy, these reforms saw the SAP move in a neo-liberal direction by the late 1980s [134]. Fiscal policy was held tight, and the slimming of the public sector would, it was argued, create crowding in effects [135: p. 349]. The public sector austerity strategy, with a profit explosion and wage restraint, was to create severe tension between the SAP and its traditions ally the LO. Thus, in this case, the economic policy instrument settings changed, but the instruments of economic policy, and the goals behind it, remained much the same: maintenance of the welfare state. This constituted a first-order policy change.

The economic crisis in Sweden generated significant debate and a form of ideational collapse occurred. However, change agents did not consolidated around a replacement economic orthodoxy. As a result, the extant economic paradigm endured, providing the existing economic policies with sufficient protection to remain largely intact despite the criticisms. There was no critical juncture in economic policy in Sweden in 1982.

Table 3. The Identification of Change in Government Policy
From Table 3 we can see that in the case of Mexico, the macroeconomic policy instruments settings, instruments, and hierarchy of goals behind macroeconomic policy, all changed. This third order policy change occurred following an economic crisis, the collapse of the dominant economic orthodoxies, the introduction of new economic ideas into the policy arena, and the consolidation of change agents around these new ideas. Together, these three factors combined, crisis, ideational change, and radical policy change, constituted a critical juncture in Mexican macroeconomic policy.

From Table $\mathbf{3}$ we can also see that in the case of Sweden there was no critical juncture in macroeconomic policy. Although there was an economic crisis, and ideational collapse occurred, change agents did not consolidate around a new site of ideas with which to manage the Swedish economy. As a consequence, the old orthodoxy on how to manage the economy endured. The result was that the hierarchy of goals behind Swedish economic policy continued on despite the economy being in crisis.

\section{CONCLUSION}

We found a critical juncture in Mexican macroeconomic policy in 1982. In the midst of an economic crisis calling into question the economic viability of the state, economic polices, having been undermined by previous failures, were overcome by change agents, led by a political entrepreneur, consolidating around a new set of ideas on how to manage the economy. The ideational foundations of extant policy collapsed in 1982 in the midst of the crisis. Import substitution and the restrictions imposed upon FDI were perceived as failing strategies. In this context, De La Madrid assumed the role of political entrepreneur, fostering an alternative set of ideas on how to manage the economy. Around these ideas change agents consolidated. These ideas involved a reversal previous policy - opening the economy to free trade and pursuing FDI. De La Madrid altered the setting, instruments, and hierarchy of goals behind Mexican economic policy - a third order policy change. Thus, there was a crisis, ideational change, and radical change in macroeconomic policy in Mexico, what the framework rates as a critical juncture in macroeconomic policy.

In the case of Sweden there was no critical juncture in macroeconomic policy in 1982. Although the economy was in crisis, and this was undermining confidence in the economic orthodoxy that had dominated society for the preceding half century, neither the non-socialist parties, or their SAP rivals, were willing to challenge this orthodoxy. Thus, although ideational collapse occurred during the crisis, a political entrepreneur willing to champion a new set of ideas on how to manage the Swedish economy failed to emerge. The result was that without such a figure, change agents, and

\begin{tabular}{|c|c|c|}
\hline The Observable Implications & Mex & Sw \\
\hline O2. If the instruments of economic policy changed there may have been radical change in economic policy & $\mathrm{X}$ & \\
\hline O3. If the hierarchy of goals behind economic policy changed there may have been a radical change in economic policy & $\mathrm{X}$ & \\
\hline Radical Change in Privatization Policy & $\mathrm{Y}$ & $\mathrm{N}$ \\
\hline
\end{tabular}


any alternative ideas, were left floundering. Extant economic policy went largely unchallenged as no alternatives were put forward. There was only a first order policy change in Sweden at the time - a change to existing policy instrument setting. Thus, although there was a crisis, and ideational collapse, no new idea was consolidated, meaning there was no ideational change. The result of this was that economic policy changed only slightly - thus there no critical juncture in Swedish macroeconomic policy at this time.

These findings show that a critical juncture in macroeconomic policy consists of three stages: macroeconomic crisis, ideational change, and radical policy change. A macroeconomic crisis is a necessary, but, in itself, insufficient, condition for a paradigm shift in macroeconomic policy to occur. A macroeconomic crisis not followed by ideational change, will not lead to a radical change in macroeconomic policy - Sweden 1982. However, a macroeconomic crisis followed by ideational change (collapse of the extant orthodoxy and consolidation of a new orthodoxy) will lead to a third order change in macroeconomic policy, which combined constitutes a critical juncture - Mexico 1982.

Thus, ideational change was very important in determining if third order macroeconomic policy change occurred in the wake of the macroeconomic crises in Mexico and Sweden. Extant ideational orthodoxy protected existing policy, ensuring its continuity. However, in the wake of the macro- economic crises, ideational collapse occurred in both countries. Existing macroeconomic policies in both countries were no longer protected, as their underlying ideas had been undermined by failure. In Mexico change agents, led by a political entrepreneur, consolidate around a new set of economic ideas, and injected these into the policy domain. The result was a third order change in macroeconomic policy. However, in Sweden change agents failed to consolidate around a new economic orthodoxy, and existing ideas endured. As a result there was only a first order policy change in Sweden. Political entrepreneur led consolidation around a new set of economic ideas was the difference between an economic crisis that lead to a critical juncture in macroeconomic policy (Mexico), and one that did not (Sweden). This ties in with the argument that different network configurations are associated with different orders of policy change [136: p. 771].

\section{ACKNOWLEDGEMENTS}

The Alßan Programme, the European Union Programme of High Level Scholarships for Latin America. We would particularly like to thank Cuauhtémoc Cárdenas, Jaime Serra Puche PhD., Luis Miguel Beristain PhD., Luis Rubio PhD., Nicolas Foucras PhD., as well as a number of other interviewees who have preferred to remain anonymous, for their help during the summer of 2008.

\section{APPENDIX A}

\section{Mexico's Economic Indicators, 1972 - 1982}

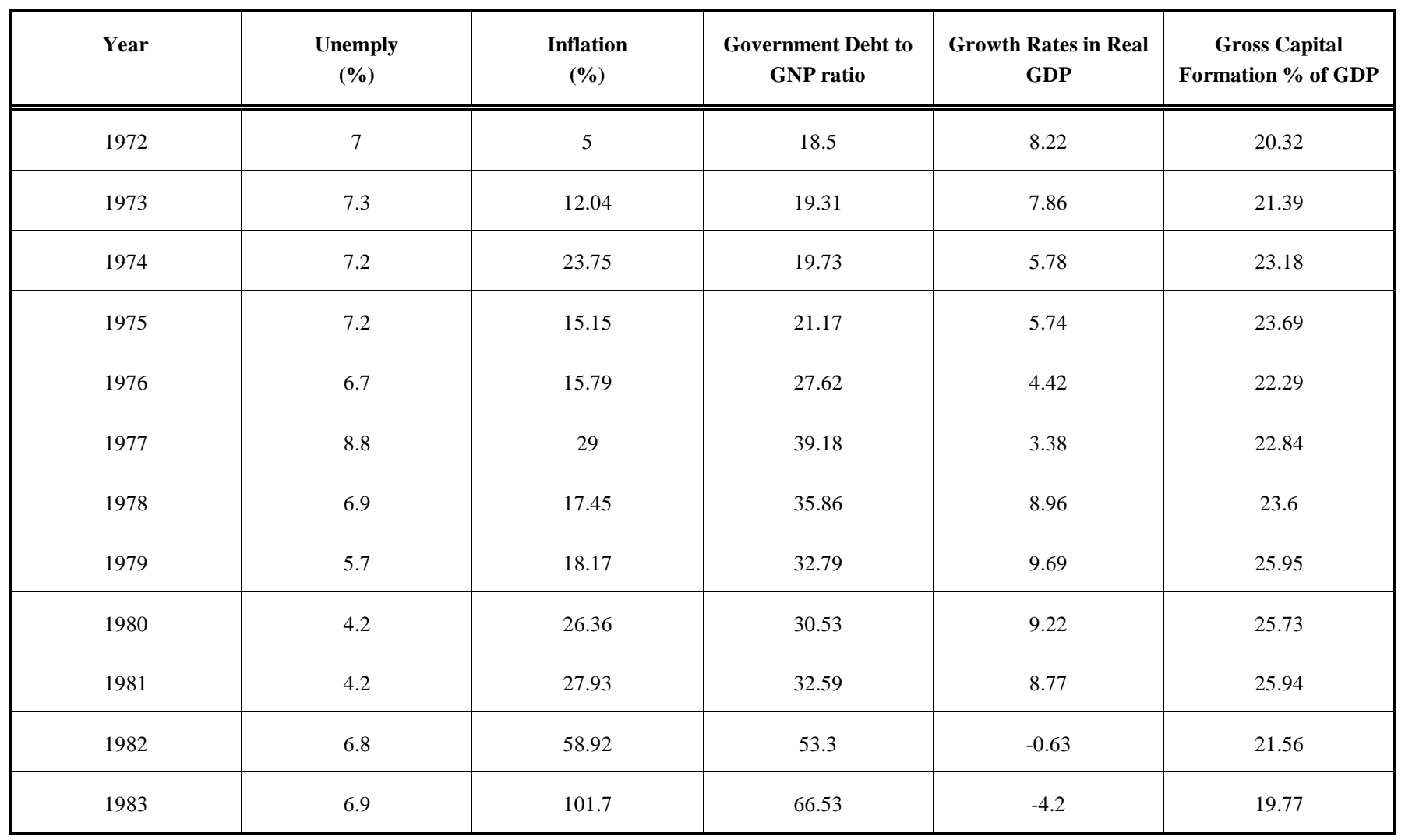

Source: Data Gob. [WWW document]. URL http://www.iadb.org/DataGob/index.html; Mitchell, R. B. (2007) International Historical Statistics: The Americas 1750-2005. $6^{\text {th }}$ ed. Macmillan: Basingstoke; Fleck, S. And Sorrentino, C. (1994) 'Employment and Unemployment in Mexico's Labour force'. Monthly Labour Review, November (3). 


\section{APPENDIX B}

\section{Sweden's Economic Indicators, 1972 - 1982}

\begin{tabular}{|c|c|c|c|c|c|}
\hline Year & $\begin{array}{c}\text { Unemply } \\
(\%)\end{array}$ & $\begin{array}{c}\text { Inflation } \\
(\%)\end{array}$ & $\begin{array}{c}\text { Government Debt to } \\
\text { GNP ratio }\end{array}$ & $\begin{array}{c}\text { Growth Rates in Real } \\
\text { GDP }\end{array}$ & $\begin{array}{c}\text { Gross Capital } \\
\text { Formation \% of GDP }\end{array}$ \\
\hline 1972 & 2.0 & 6.0 & 22.2 & 2.2 & 23.45 \\
\hline 1973 & 2.5 & 6.7 & 22.6 & 3.9 & 22.65 \\
\hline 1974 & 2.0 & 9.9 & 24.2 & 4.3 & 25.27 \\
\hline 1976 & 1.6 & 10.3 & 23.6 & 1.2 & 24.90 \\
\hline 1977 & 1.8 & 11.4 & 26.5 & -2.0 & 21.68 \\
\hline 1978 & 2.2 & 10.0 & 31.8 & 1.3 & 18.69 \\
\hline 1979 & 2.1 & 7.2 & 37.9 & 4.3 & 21.22 \\
\hline 1982 & 3.1 & 8.6 & 59.3 & 1.1 & 19.29 \\
\hline 1983 & 3.5 & 9.0 & 64.6 & 1.8 & 19.02 \\
\hline
\end{tabular}

Source: Data Gob. [WWW document]. URL http://www.iadb.org/DataGob/index.html; OECD, 1995. Labour Force Statistics. OECD: Paris; Statistical Annex of European Economy, Spring 2003; Eurostat Yearbook 1997. Luxembourg: Office for Official Publications of the European Communities; Mitchell, B. R., 1993. International Historical Statistics. Europe 1750-1988. ( $3^{\text {rd }}$ ed.) Hong Kong: Stockton Press; Alan Heston, Robert Summers and Bettina Aten, Penn World Table Version 6.1, Center for International Comparisons at the University of Pennsylvania (CICUP), October 2002.

\section{REFERENCES}

[1] Hogan JW, Doyle D. Macroeconomic policy change: Ireland in comparative perspective. Irish Polit Stud 2008; 23(1): 77-97.

[2] Mahoney J. Path dependence in historical sociology. Theory Soc 2000; 29(4): 507-48.

[3] Mahoney J. Long-run development and the legacy of colonialism in Spanish America. Am J Sociol 2003; 109(1): 50-106.

[4] Pierson P, Skocpol T. Historical institutionalism in contemporary political science. In: Katznelson I, Milner HV, Eds. Political science: state of the discipline. New York, NY: W.W. Norton 2002; pp. 693-721.

[5] Mahoney J. Path dependent explanations of regime change: Central America in comparative perspective. Stud Comp Int Dev 2001; 36(1): 111-41.

[6] Collier RB, Collier D. Shaping the Political Arena: Critical Junctures, the labour movement, and regime dynamics in latin America. Princeton, NJ: Princeton University Press 1991.

[7] Garrett G, Lange P. Internationalization, institutions, and political change. Int Org 1995; 49(4): 627-55.

[8] Casper G, Taylor MM. Negotiating democracy: transitions from authoritarian rule. Pittsburgh, PA: University of Pittsburgh Press 1996.

[9] Hogan JW. Testing for a critical juncture: change in the ICTU's influence over public policy in 1959. Irish Polit Stud 2005; 20(3): 23-43.

[10] Hogan JW. Remoulding the critical junctures approach. Can J Polit Sci 2006; 39(3): 657-79.

[11] Karl TL. The politics of plenty: oil booms and petro-states. Berkeley, CA: University of California Press 1997.

[12] Flockhart T. Critical junctures and social identity theory: explaining the gap between Danish mass and elite attitudes to Europeanization. J Common Mark Stud 2005; 43(2): 251-71.

[13] Lijphart A. Patterns of democracy: government forms and performance in thirty-six countries. New Haven, Conn: Yale University Press 1999.

[14] Collier D. Comparative-historical analysis: where do we stand? APSA-CP News lett 1998; 9(2): 1-5.

[15] Feldstein M. American economic policy in the 1980s. Chicago, Ill: University of Chicago Press 1994.
[16] Haggard S, Kaufman RR. The political economy of democratic transitions. Princeton, NJ: Princeton University Press 1995.

[17] Stevenson RT. The economy and policy mood: a fundamental dynamic of democratic politics? Am J Polit Sci 2001; 45(3): 62033 .

[18] Pemberton H. Policy networks and policy learning: UK economic policy in the 1960s and 1970s. Public Adm 2000; 78(4): 771-92.

[19] Taylor JB. Macroeconomic policy in the world economy. New York, NY: W.W. Norton 1993.

[20] Legro JW. The transformation of policy ideas. Am J Polit Sci 2000; 44(3): 419-32.

[21] Hall PA. Policy paradigms, social learning, and the state: the case of economic policy making in Britain. Comp Polit 1993; 25(3): 275-96.

[22] Garrett G. The politics of structural change: Swedish social democracy and Thatcherism in comparative perspective. Comp Polit Stud 1993; 25(4): 521-47.

[23] Yu L, Lai KK, Wang S-Y. Currency crisis forecasting with general regression neural networks. Int J Info Technol Decis Mak 2006; 5(3): 437-54.

[24] Stone DA. Causal stories and the formation of policy agendas. Polit Sci Q 1989; 104(2): 281-300.

[25] Kaminsky GL, Lizondo S, Reinhart C. Leading indicators of currency monetary fund staff crises. Int Monet Fund Staff Pap 1998; 45(1): $1-48$.

[26] Berg A, Pattillo C. Predicting currency crises: the indicators approach and an alternative. J Money Finance 1999; 18: 561-86.

[27] Pei M, Adesnik AD. Why recessions don't start revolution. Foreign Policy 2000; 118(1): 138-51.

[28] Frankel JA, Rose A. Currency crashes in emerging markets: an empirical treatment. J Int Econ 1998; 41(2): 351-66.

[29] Garuba, Dauda S. Survival at the margins: economic crisis and coping mechanisms in rural Nigeria. Local Environ 2006; 11(1): 17-36.

[30] Kwon S. Economic crisis and social policy reform in Korea. Int J Soc Welfare 2001; 10(2): 97-106.

[31] Solimano A. Political crises, social conflict and economic development: the political economy of the andean region. Cheltenham: Edward Elgar 2005. 
[32] González S. The politics of the economic crisis and restructuring in the Basque country and Spain during the 1980s. Space Policy 2005; 9(2): 93-112.

[33] Blyth M. Great transformations: economic ideas and institutional change in the twentieth century. Cambridge: Cambridge University Press 2002.

[34] Hay C. Crisis and the structural transformation of the state: interrogating the process of change. Br J Polit Int Relat 1999; 1(3): 31744.

[35] Narula R. Switching from import substitution to the "New Economic Model" in Latin America: A case of not learning from Asia. Strategic Management Society Annual Conference, Paris, France: Copenhagen Business School and University of Oslo, Working paper No. 4. September 2002.

[36] González ML. La Industrialización en México/The Industrialization in Mexico. Álvaro Obregón, México, DF: Porrua Miguel Angel S a 2002.

[37] Solis L. Mexican economy policy in the post-war period: the views of mexican economists. Am Econ Rev Suppl Surv Natl Econ Policy Issues Policy Res 1971; 61(3): 2-67.

[38] Hernandez LMB. PhD in Administrative Sciences. Business and Politics professor, Director of Professional Development, Enterprise Development and Social Development at ITESM (Interviewed July 2008).

[39] Serra-Puche J. PhD in Economics. Mexican Politician. Secretary of Commerce and Industry in 1988; Treasury Secretary in 1994; and Mexico's representative in NAFTA negotiations in early 1990s. (Interviewed June 2008).

[40] Rubio L. PhD in Political Science. Mexican writer on politics, and economics. (Interviewed July 2008).

[41] Alarcon D, McKinley T. Beyond import substitution: the Restructuring projects of Brazil and Mexico. Lat Am Perspect 1992; 19(2): 72-87.

[42] Calderón-Madrid A. Incomplete adjustment: fiscal policy, private savings and current account deficits in Mexico since 1982. In: Jansen K, Vos R, Eds. External finance and adjustment, failure and success in the developing world. London: Macmillan Press LTD 1997; pp. 45-67.

[43] Nelson JM. Economic crisis and policy change. Princeton, NJ: Princeton University Press 1990.

[44] Tournaud NF. PhD in Political Science. Head of the Political Science department, ITEMS (Instituto Tecnológico y De Estudios Superiores de Monterrey) Campus Monterrey. (Interviewed August 2008).

[45] Clavijo F, Valdivieso S. Reformas Estructurales y Política Macroeconómica: El Caso de México 1982-1999/Structural Reforms and Macroeconomic Policy: The Case of Mexico 1982-1999. Santiago: Comision Economica para America Latina y el Caribe 2000.

[46] Solís L. Economic policy reform in Mexico. A case study for developing countries. Elmsford, NY: Pergamon 1981.

[47] Fitzgerald EVK. Capital accumulation in Mexico. J Latin Am Stud 1978; 10(2): 263-82.

[48] McCaughan EJ. Mexico's long crisis: toward new regimes of accumulation and domination. Latin Am Perspect 1993: 20(3): 631 .

[49] Nash J. Mexico: adjustment and stabilisation. In: Thomas V, Chhibber A, Dailami M, de Melo J, Eds. Restructuring Economies in Distress: Policy Reform and the World Bank. Oxford: Oxford University Press 1991; pp. 494-515.

[50] Byron C, Malkin L, Ungeheuer F. Plunging petroleum prices. Time Magazine. New York, NY: 22 February, 1982, p. 12.

[51] Magazine Nexos, Sociedad, Ciencia y Literatura,. De Díaz Mirón a Díaz Serrano. Mexico City, Mexico: Magazine Nexos January, 1982.

[52] Staar PK. Mexican Foreign Policy. In: Randall, L, Ed. Changing structure of Mexico: political, social, and economic prospects. $2^{\text {nd }}$ ed., New York, NY: M.E. Sharpe 2006.

[53] Cornelius WA. The political economy of mexico under de la madrid: austerity, routinized crisis, and nascent recovery. Mexican Stud 1985; 1(1): 83-124.

[54] Sancton TA, Lopez L, Ungeheuer F. Frightening specter of bankruptcy. New York, NY: Time Magazine 30 August 1982, p. 40.

[55] Dornbusch R, Sebastian E. The macroeconomics of populism in Latin America. Chicago, Ill: The University of Chicago Press 1991.
[56] Katz I. Macroeconomic stabilisation and structural change in the Mexican economy. Discussion Papers Economics 1994; 3: 1-24.

[57] Russell G, Bolte G, Lopez L. We are in an emergency. New York, NY: Time Magazine. 20 December 1982; p. 30.

[58] Malkin L, Greenwald J, Earle M. The cartel is losing its clout. New York, NY: Time Magazine 1 January 1983; p. 27.

[59] Pico I. Mexico dead men don't pay up. New York, NY: Time Magazine 23 June 1986; p. 21.

[60] Edwards S. Crisis and reform in Latin America: from despair to hope. Washington, DC: Oxford University Press 1995.

[61] Brandford S. IMF: quick fix - slow poison. Third World Magazine. London: October 1983.

[62] Ortiz GC. Privatización de la Banca en México/Privatization of the Banks in Mexico. Mexico City: Gestión y Estrategia, (1) July 1991

[63] Pico I. On the firing line. New York, NY: Time Magazine 13 July, 1987, p. 15.

[64] Time to Put Paid to Aid. London: The Economist 6 April, 1985.

[65] México en crisis económica. El País. Madrid: 1 January 1983; p. 4.

[66] Colmenares D, Angeles L, Ramirez C. La Devaluación de 1982. Mexico, DF: Terra Nova 1982; p. 7.

[67] Third World Magazine. London: December, 1983.

[68] Lustig N. El precio Social del Ajuste Mexicano: Balance de sombras/The Social Price of Mexican Adjustment. Mexico City, Mexico: Magazine Nexos, Sociedad, Ciencia y Literatura October 1986.

[69] Basañez M. México 1985: Un pronóstico Electoral. La Lucha por La Hegemonía en México. 1968-1980/Mexico 1985: An Electoral prognosis. Lucha by the Hegemony in Mexico. 1968-1980. Mexico City, Mexico: Magazine Nexos, Sociedad, Ciencia y Literatura July 1985.

[70] Warnock J. The other Mexico: The North American triangle completed. London: Black Rose Books 1995.

[71] Katz I. The Mexican Economy on the way to recovery. Discussion Papers Economics 1996; 40: 1-11.

[72] Jacobs E, Bendesky L, Dehesa M, et al. conomía Mexicana/Mexican Economy. Mexico City, Mexico: Magazine Nexos, Sociedad, Ciencia y Literatura February 1982

[73] Jiménez M. Las crisis económicas de México en 1976 y 1982 y su relación con la criminalidad. J Humanit Soc Sci 2006; 11(3): 27-32.

[74] Latin America Regional Report. Central American and Mexico, 13 August 1982; p. 1.

[75] Portillo L. Sixth Annual Presidential Report of President López Portillo, September $1^{\text {st }}, 1982$.

[76] Sandersen SE. Presidential succession and political reality in Mexico. World Polit 1983; 35(3): 315-34.

[77] Bailey JJ. Presidency, bureaucracy, and administrative reforms in Mexico: The secretariat of programming and budget. Int Am Econ Aff 1988; 34(2): 27-59.

[78] Barker T, Brailovsky V. Recuento de la Quiebra/Counting the Bankruptcy. Mexico City, Mexico: Magazine Nexos, Sociedad, Ciencia y Literatura. November 1983.

[79] Wengel JT, Chalapati RKSC, Visser H. Lecciones De Las Crisis Mexicanas Para Corea/Lessons of the Mexican Crisis for Korea. Trimest Econ 2000; 67(265): 27-46.

[80] Byron C, Branegan J. Why bankers have the jitters. New York, NY: Time Magazine 20 September 1982; p. 23.

[81] Siven C.-H. The political economy of Sweden in the 1970s. Department of Economics - University of Stockholm, Research Papers in Economics 1984; No. 1.

[82] Dullforce W. Crucial decisions in the Offing. London: Financial Times. 9 December 1982; p. 18.

[83] Organization for Economic Cooperation and Development. Sweden. Paris: OECD 1982

[84] Another Swedish pink movie? London: The Economist 28 August 1982.

[85] Apple JW. Palme wins major victory in Sweden. New York, NY: The New York Times, 20 September, 1982, p. 3.

[86] Mitchell BR. International historical statistics. Europe 1750-1988, $3^{\text {rd }}$ ed. Hong Kong: Stockton Press 1993.

[87] Osnos P. Palme to push world role for Sweden. Washington, DC The Washington Post 21 September 1982; p. A15.

[88] Apple RW. Social democrats favored in Sweden. New York, NY: The New York Times, 18 September 1982; p. 17. 
[89] Dullforce W. Fears for the welfare state. Financial Times. London: 18 September 1982; p. 15.

[90] Organisation for Economic Cooperation and Development. Sweden, Paris: OECD 1984.

[91] Organisation for Economic Cooperation and Development. Sweden, Paris: OECD 1990.

[92] Gress D. The Nordic countries. In: Dorfman GA, Duignan PJ, Eds. Politics in Western Europe. Stanford, CA: Hoover Press 1988; pp. 202-19.

[93] Peterson RB. Swedish collective bargaining - a changing scene. Br J Ind Relat 1987; 25(1): 31-48.

[94] Lindbeck A. The Swedish experiment. J Econ Lit 1997; 35(4): 1273-319.

[95] Levy JS. Learning and foreign policy: sweeping a conceptual minefield. Int Organ 1994; 48(2): 279-312.

[96] McNamara KR. The currency of ideas: monetary politics in the European Union. Ithaca, NY: Cornell University Press 1998.

[97] Golob S. Beyond the policy frontier: Canada, Mexico, and the ideological origins of NAFTA. World Polit 2003; 55(3): 361-98.

[98] Dahl R. Who governs? Democracy and power in an American city. New Haven, NJ: Yale University Press 1961.

[99] Sheingate AD. Political entrepreneurship, institutional change, and American political development. Stud Am Polit Dev 2003; 17(2): 185-203.

[100] Kingdon J. Agendas, alternatives, and public policy. $2^{\text {nd }}$ ed. New York, NY: Harper 1995.

[101] Oliver MJ, Pemberton H. Learning and change in 20th-century British economic policy. Governance 2004; 17(3): 415-41.

[102] Blyth M. The transformation of the Swedish model: economic ideas, distributional conflict and institutional change. World Polit 2001; 54(1): 1-26.

[103] Woodhead L. Mexico from bust to boom: a political evaluation of the 1976- 1979 stabilization programme. World Dev 1980; 8(1): 843-64.

[104] Prest M. Gold goes alone as the bulls dig in. London: The Times 10 September 1982; p. 7.

[105] Taylor AL, Lopez L. Mexico's petroleum hangover. New York, NY: Time Magazine 29 March 1982; p. 38.

[106] Lopez L. A Successor for Lopez Portillo. New York, NY: Time Magazine 5 October 1981; p. 21.

[107] Villegas DC. La sucesion presidential. Mexico: Cuadernos de Joaquin Mortiz 1981.

[108] Luna M, Tirado R, Valdes F. Businessmen and politics in Mexico, 1982 -1986. In: Maxfield S, Anzaldua R, Eds. Government and Private Sector in Contemporary Mexico. Center for US-Mexican Studies San Diego 1987; pp. 168-202.

[109] Cárdenas C. Mexican politician, key political figure in Mexico's politics in the 1980s and important political representative of Mexico's opposition parties (Partido de la Revolución Democrática [PRD]) 1980.

[110] Latin America Regional Reports. Mexico and Central America. Longon: 4 June, 1-2, 1982.

[111] First Annual Presidential Report of President Miguel De La Madrid, 1September, 1983.

[112] Lustig N, Ros J. Stabilisation and Adjustment in Mexico: 19821985 (Paper for the UNI.Winder conference on "Stabilization and Adjustment Programs and Policies," Helsinki, 19-21 August 1986.
[113] Colmenares D, Angeles L, Ramirez C. La Devaluación de 1982. Mexico, DF: Terra Nova 1982.

[114] Aboites J. Acumulación, reproducción de la fuerza de trabajo y crisis en México. Mexico: Economía Teoría y Práctica 1983; p.1.

[115] Lustig N. Mexico: the remaking of the economy. Washington, DC: The Brookings Institute 1992.

[116] Pastor M, Wise C. State policy, distribution and neoliberal reform in Mexico. J Latin Am Stud 1997; 29(2): 419-56.

[117] http://www.const.sns.se/swedishpolitics/

[118] Pontusson J. Behind and beyond social democracy in Sweden. New Left Rev 1984; 143(1): 69-96.

[119] Hadenius S. Swedish politics during the $20^{\text {th }}$ century - conflict and consensus. Stockholm: Svenska Institute 1997.

[120] Looney RE. Economic policymaking in mexico: factors underlying the 1982 crisis. Durham, NC: Duke University Press 1985.

[121] Lustig N. Mexico: the remaking of the economy. $2^{\text {nd }}$ ed. Washington, DC: The Brookings Institute 1998.

[122] IGS. Mexican crisis and response. Econ Polit Wkly 1982; 17(43): 1720.

[123] Soria VM. Caracterización de la crisis de 1976 y 1982 en México. Universidad Autónoma Metropolitana, Mexico City: Economía Teoría y Práctica Magazine 1983; p. 1

[124] Middlebrook KJ. Dilemmas of political change in Mexico. London: Institute of Latin America Studies, University of London 2004.

[125] Mexico in Crisis. Latin America Regional Reports 4 June 1982; pp. 1-2.

[126] Nicolas F, PhD in Political Science. Head of the Political Science department, ITEMS (Instituto Tecnológico y De Estudios Superiores de Monterrey) Campus Monterrey (Interviewed July 2008).

[127] Lustig N. Life is not easy: Mexico's Quest for stability and growth J Econ Perspect 2001; 15(1): 85-106.

[128] Martin A. The politics of macroeconomic policy and wage negotiations in Sweden. In: Iversen T, Pontussson J, Soskice D, Eds. Unions, Employers, and Central Banks. New York: Cambridge University Press 2000; pp. 232-266.

[129] Apple JW. For palme, some thorns on the roses. The New York Times. New York, NY: 21 September 1982; p. 3.

[130] Dullforce W. Sweden raises taxes in 'crisis' economic plan. Financial Times London. London: 12 October 1982; p. 1.

[131] Swedes Devalue by 16\%, Freeze Prices and Provoke Criticism from Norway, The Washington Post. Washington, DC: 8 October, 1982; A16.

[132] Fransworth CH. Amid slump, trade-offs in World Trade seem unlikely. The New York Times. New York, NY: 21 November, 1982; p. 3.

[133] Ahlén K. Swedish collective bargaining under pressure: interunion rivalry and incomes policies. Br J Ind Relat 1989; 23(3): $330-46$.

[134] Taylor R. Sweden's left feels the chill wind of change. London: Financial Times 1991; p. 3.

[135] Mjoset L. The Irish economy in a comparative institutional perspective. Dublin: NESC 1992.

[136] Pemberton H. Policy networks and policy learning: UK Economic Policy in the 1960s and 1970s. Public Adm 2000; 78(4): 771-92.

(c) Maza and Hogan; Licensee Bentham Open.

This is an open access article licensed under the terms of the Creative Commons Attribution Non-Commercial License (http://creativecommons.org/licenses/ by-nc/3.0/) which permits unrestricted, non-commercial use, distribution and reproduction in any medium, provided the work is properly cited. 